\title{
РЕАЛІЗАЦІЯ РЕФЛЕКСИВНОЇ МОДЕЛІ ПРАКТИКИ ОСВІТИ У СУЧАСНІЙ ФІНСЬКІЙ ШКОЛІ
}

У статті розглядається приклад краӥни, освітня система якої увібрала $b$ себе ідеї філософських концепцій критичного мислення I. Канта та М. Ліпмана. Адже саме завдяки динамічним інтеграційним процесам у світі, ми звертаємо увагу на рефлексивні моделі освіти, які приводять нас до запитання : Що ж на съогоднішній день є більш актуальним заучування інформачї чи ї критичний аналіз?

У статті зроблена спроба дослідити організацію навчання у фінських школах через призму рерлексивної моделі І. Канта та рефлексивної моделі практики освіти М. Ліпмана.

I. Кант у свойї роботі "Критика чистого розуму" використовував поняття рефлексії з метою роз'яснення специфіки роботи свідомості. Він поділяв поняття рефлексії на трансцендентальну $i$ логічну. Логічна рефлексія тільки поріВнлюе поняття між собою $і$ не може судити про речі апріорі. Трансцендентальна рефлексія - підстава можливості об'єктивного порівняння уявлень одне з одним.

Спираючись на положення із робіт І. Канта про рефлексію як спосіб утворення нових понять і суджень через порівняння Вже наявних уявлень, М. Ліпман запропонував рефлексивну модель освіти, якій присвячена його робота «Рефлексивна модель практики освіти».

Також у статті проаналізована роль феномено-орієнтованого навчання та викладання (phenomenon-based teaching and learning) $y$ вихованні критичного мислення, яке необхідне для успішної життедіяльності особистості в сучасному інформачійному суспільстві. Фінляндія на практиці демонструє, як вивчення феноменіВ допомагає учневі не просто зрозуміти те, що відбувається, а й підштовхує його до формулюВання самостійної думки з будь-якого життевого питання. Таким чином створюеться підхід під назвою "рефлексивна модель освіти", яка $b$ повній мірі розглядалася I. Кантом $b$ сфрері філософії, а М. Ліпманом у сфері психології і педагогіки.

У статті зроблена спроба аргументувано довести, що організачія процесу навчання у фінській школі має ознаки рефлексивної парадигми критичної практики, що є неВід'ємною особлиВістю фрінської системи освіти на сучасному етапі їі розвитку.

Досвід організачії навчання у фінськіій иколі може бути використаний при розбудові нової украйнської иколи.

Ключові слова. рефлексія, рефлексивна модель практики освіти, критичне мислення, критерії, судження, феномени, феномено-орієнтоване навчання і викладання. 


\section{IMPLEMENTATION OF REFLECTIVE MODEL OF EDUCATIONAL PRACTICE IN THE MODERN FINNISH SCHOOL}

The article considers the example of a country whose educational system has absorbed the ideas of philosophical concepts of critical thinking of I. Kant and M. Lipman. After all, thanks to the dynamic integration processes in the world, we pay attention to reflective models of education, which lead us to the question: What is more relevant today - memorization of information or its critical analysis?

The article attempts to investigate the organization of education in Finnish schools through the prism of I. Kant's reflexive model and M. Lipman's reflexive model of educational practice.

I. Kant in his work "Critique of Pure Reason» used the concept of reflection in order to explain the specifics of the work of consciousness. He divided the concept of reflection into transcendental and logical. Logical reflection only compares concepts with each other and cannot judge things a priori. Transcendental reflection - the basis for the possibility of objective comparison of ideas with each other.

Based on the provisions of Kant's work on reflection as a way of forming new concepts and judgments through the comparison of existing ideas, M. Lipman proposed a reflective model of education, which is devoted to his work «Reflective model of educational practice.

The article also analyzes the role of phenomenon-based teaching and learning in the education of critical thinking, which is necessary for the successful life of the individual in the modern information society. The Finnish school shows us that the study of phenomena helps the student not only to understand what is happening, but pushes him to formulate an independent opinion on any issue in life. This creates an approach called "reflective model of education", which was fully discussed by I. Kant in the field of philosophy, and M. Lipman in the field of psychology and pedagogy.

The article attempts to argue that the construction of the learning process in the Finnish school has the features of a reflexive paradigm of critical practice, which is its integral feature.

The experience of organizing education in a Finnish school can be used in the development of a new Ukrainian school.

Key words. reflection, reflective model of educational practice, critical thinking, criteria, judgments, phenomena, phenomenon-oriented learning and teaching.

Розбудова якісної конкурентоспроможної системи освіти в Україні зумовлена потребами соціально-економічного, духовного і культурного розвитку нашої держави, зміцнення ії міжнародного авторитету й іміджу, створення умов для самореалізації кожного ії громадянина.

У кінці XX - на початку XXI століття в Україні активізувалися пошуки 
вітчизняними ученими у галузі зарубіжної теорії та практики прикладів і вартих наслідування зразків функціонування систем освіти, впровадження досягнень яких сприятиме удосконаленню освітньої системи України. Так, окремі аспекти системи освіти США досліджуються у роботах Л. Кнодель, О. Тарасової, М. Шутової та ін.; Великобританії - Н. Воскресенської, Н. Дічек, Л. Заблоцької, В. Лапчинської, О. Сєргєєвої та ін.; Німеччини В. Гаманюк, Л. Писарєвої та ін.; Франції - О. Бочарової, Л. Зязюн, О. Хміль та ін.; Японії - О. Бібко, І. Зязюна, Л. Савранчук та ін.; Чехії - Н. Бондарчук та ін.; у країнах Євросоюзу - Т. Кристопчук та ін.

Вагомим для України є досвід Фінляндії, система освіти якої за «загальним визнанням експертів у сфері освіти та за результатом міжнароджних досліджень ТНСС, ПІЗА, ПІРЛЗ є однією з найкращих, якщо не найкращою освітньою системою у світі» [1, с. 1], а за результатами Індексу ефективності національних систем освіти (Global Index of Cognitive Skills and Educational Attainment) у 2016 р. вона посіла 6 місце (а Україна 42) $[10$, c. 38].

Окремі аспекти системи освіти Фінляндії досліджуються у роботах В. Бутової (шкільна освіта у Фінляндії), Л. Волинець (принципи освітньої політики у Фінляндіï), С. Гринюк (принципи побудови успішної системи

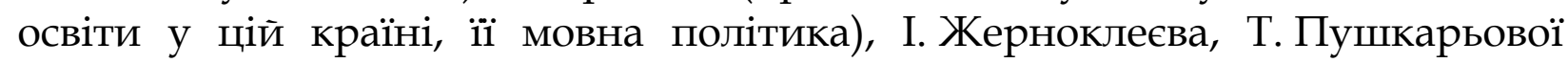
(система освіти Фінляндії), В Загвоздкіна, М. Писаревського (чинники успіху фінської системи освіти, реформування іiі), В. Лунячека (досвід Фінляндії у створенні адаптивних систем управління освітою в Україні) та iH.

Попри те, що значна увага сучасними науковцями приділяється питанням функціонування системи освіти Фінляндії, аналізу теоретичних засад організації навчання у освітніх закладах та деяким іншим суттєвим для освітньої системи аспектам, на нашу думку, вони через динамічні зміни як у суспільному житті, так і у розвитку освітньої системи потребують подальшої розробки

Метою статті $є$ аналіз фінської системи освіти через призму рефлексивної моделі І. Канта та рефлексивної моделі практики освіти М. Ліпмана.

Виклад основного матеріалу. Рефлексія - це «роздум про свій внутрішній стан, самоаналіз» [9], «міркування, повне сумнівів, протиріч; аналіз власного стану» [13]; «рефлексія (від лат. reflexio - обернення назад) процес осмислення чого-небудь за допомогою вивчення і порівняння. У вузькому сенсі - «новий поворот» духу після скоєння пізнавального акту до Я (як центру акта) і його мікрокосмосу, завдяки чому стає можливим привласнення пізнаного [14].

Хоча поняття «рефлексії» не $\epsilon$ новотвором i відоме науковцям, Д. Жадяєв, наприклад, вважає, що філософське поняття рефлексії практично не розкрите [3]. Дослідник проаналізував зміни дефініцій цього поняття в історії філософії та його трактування І. Кантом [3] і дійшов цілком аргументованого висновку, що Платон і Аристотель трактували 
мислення i рефлексію як атрибути божественного Розуму, через які проявляється єдність можливого і думки. В епоху Нового часу Р. Декарт під рефлексією розумів основний методологічний принцип філософії. Шляхом рефлексії знаходиться точка відліку істини: cogito ergo sum. Згідно Дж. Локка, рефлексія носить емпіричний характер i відноситься до внутрішнього досвіду мислячого суб'єкта. Г. Лейбніц поділяв пізнання на емпіричне і логічне (інтелектуальне), пов'язуючи своє поняття рефлексії із загальним знанням і загальними істинами [3].

Д. Жадяєв вказує, що І. Кант у своїй філософії використовував поняття рефлексії з метою роз'яснити специфіку роботи свідомості. У роботах «Про форму і принципи чуттєво сприйманого і інтелігібельного світу», «Критика чистого розуму» I. Кант розкрив поняття рефлексії як такої, що виконує інтегруючу функцію між двома сферами : чуттєвою та інтелектуальною, як те, що пов'язує явище і досвід. Поняття рефлексії у I. Канта - це відповідь його попередникам, які розвели способи пізнання у протилежні сторони і не могли прийти до об'єктивного рішення, відстоюючи кожен свої позиції. Саме рефлексію німецький мислитель підключив до вирішення суперечки між раціоналістами й емпіриками. Через рефлексивну модель він хотів не просто навчити розумності, а навчити людей самостійному мисленню [3].

У «Критиці чистого розуму», визначаючи дане поняття, I. Кант говорить, що «reflexio» не має справи із самими предметами, щоб отримувати поняття прямо від них; вона $є$ такий стан душі, в якому ми перш за все намагаємося знайти суб'єктивні умови, при яких можемо утворити поняття [5]. Тут мається на увазі, вважає Д. Жадяєв, що рефлексія суть такого стану душі, завдяки якому людська свідомість може правильно визначити до якого джерела пізнання - чуттєвості або розуму - відносяться дані уявлення [3].

Для більшої ясності, I. Кант ділить поняття рефлексії на трансцендентальну і логічну. Дослідження типології трансцендентальної рефлексії у філософії І. Канта знаходимо в роботі А. Кузьміна «Типология трансцендентальной рефлексии в философии И. Канта» [6]. Трансцендентальною рефлексією, згідно I. Канту, є дія, якою людина пов'язує порівняння уявлень взагалі з пізнавальною здатністю (чуттєвістю або розумом), що виробляє його, і яким вона розпізнає чи порівнює уявлення одне 3 одним як такі, які належать до чистого розуму або до чуттєвого споглядання. Логічна рефлексія тільки порівнює поняття між собою і не може судити про речі апріорі. Трансцендентальна рефлексія може визвати тотожність чи відмінність речей, їх узгодженність або протиріччя між ними і т. п. не просто порівнюючи (comparatio), a розрізняючи сам спосіб пізнання, до якого вони належать. «Трансцендентальна рефлексія - підстава можливості об'єктивного порівняння уявлень одне з одним», - вважає А. Кузьмін [6].

Кантівська філософія вперше поставила питання про логічне виведення принципів пізнання, а також про можливість їх застосування до способу такого виведення, а його ідеї й досі, вже у XXI столітті залишаються 
актуальними і слугують відправною точкою для нових ідей і теорій. Так, спираючись на положення праць великого німецького філософа про рефлексію як «спосіб утворення нових понять і суджень через порівняння вже наявних уявлень», американський дослідник М. Ліпман запропонував рефлексивну модель освіти, якій присвячена його робота під назвою «Рефлексивна модель практики освіти» [7].

Науковець вважає, що школа - це поле битви, оскільки вона більше, ніж інший соціальний інститут, формує суспільство майбутнього. Тому кожна соціальна група чи фракція прагне контролювати школу в ім'я своїх власних цілей.

Коли школа розглядається переважно як представник всіх, а не якоїсь однієї соціальної групи, вона здатна зберегти право на неупередженість. 3 іншого боку, в цьому випадку школа може перетворитися в дуже консервативний, навіть традиціоністський інститут. «Саме така школа сьогодні в нашому суспільстві», - робить висновок М. Ліпман. [7, с. 91]

Освіта завжди ставила перед собою дві принципові мети - передавати знання та культивувати мудрість. Але в часи суспільних змін знання дуже швидко старіють, тому в такі періоди люди віддавали перевагу інтелектуальній гнучкості та винахідливості.

Сучасна концепція освіти (education as inquiry) поєднує обидві зазначені цілі. «Вона наголошує однаковою мірою як на процесі, так і на його результаті : на мисленні і на знанні, на дослідженні і на знайденій завдяки йому істині», - вказує науковець [8, с. 33].

Організуючим принципом школи як соціального інституту $\epsilon$ раціональність. Школи підлягають принципам раціональності, однак демократичне суспільство більш за все потребує розумних громадян, вважає М. Ліпман. Саме такі завдання - розбудувати демократичне суспільство та готувати освічених громадян, яким властиве критичне мислення, вміння висловлювати власні судження, намагається сьогодні розв'язувати українське суспільство.

Як же слід навчати таких громадян, «щоб вони стали розумними?» ставить запитання цей дослідник і відповідає на нього [7, с. 92]. Науковець вважає, що справа не просто в необхідності раціональної організації школи. Головне полягає в тому, що для одержання більш розумних людей 3 учнями, які пропускаються через школу, слід поводитися розумно. Це значить, що кожний аспект шкільного навчання повинен мати раціональне виправдання. Діти, виховані в системі розумних громадських інститутів, мають більше шансів стати розумними, а ніж діти, які виросли не в раціональних умовах.

Чи можна навчити розумності, не навчаючи мисленню? 3 цією дилемою зіткнувся І. Кант, вважає М. Ліпман. Німецький філософ щиро бажав, щоб люди думали самостійно і був близький до ідеї навчання цьому поки вони ще знаходяться в дитячому віці. Однак, самостійне мислення, яке мав на увазі І. Кант, не означало повноцінної участі в дослідженнях, тобто тієї діяльності, що пропонується зараз. Скоріше передбачалось добровільне 
підпорядкування кожного індивіда загальним універсальним принципам. Саме про це писав І. Кант у своїй статті «Що таке просвіта?» [7, с. 93].

Багато авторів відзначають і коментують той факт, що через якийсь час перебування в школі допитливість, багата уява дітей поступово щезають, «перебування $з$ ровесниками є єдиним шансом спасіння, освітня сторона справи - важким випробуванням», відзначає М. Ліпман [7, с. 93].

Шлях до вирішення цієї проблеми пов'язаний з розробкою процедур, які заохочують як до удосконалення організації, так і до здійснення творчої діяльності. Науковець, посилаючись на роботу Д. Дьюї «How we think», наводить цитату: «Проблема методу в формуванні навичок рефлексивного мислення - це проблема створення умов, які породжують і направляють допитливість; виявлення зв'язків, наявних у досвіді, об'єктах, що пізніше викличе потік здогадок, поставить проблеми та цілі, які сприяють установленню послідовності в ланцюгу ідей» [7, с. 94-95].

Слід відзначити, що саме Д. Дьюї першим запропонував дефініцію поняття «рефлексивне мислення» у цій роботі [1].

М. Ліпман звертає особливу увагу на практику, під якою він розуміє «будь-яку методичну діяльність» i проводить розмежування між «звичайною» i «критичною» практикою [7, с. 97]. У своїх роздумах науковець виходить із наявності двох чітко протилежних парадигм освітньої практики - стандартної парадигми звичайної практики і рефлексивної парадигми критичної практики.

Не вдаючись до характерних ознак стандартної парадигми, які називає автор, звернемо увагу на домінуючі ознаки рефлексивної парадигми:

- навчання - це результат участі у керованому вчителем дослідницькому співтоваристві, однією 3 цілей якого $є$ досягнення розуміння і хорошого судження;

- учнів мотивують розмірковувати про всесвіт, уявляючи наше знання про нього як двозначне, не визначене і загадкове;

- дисципліни, в рамках яких відбувається дослідження, не вважаються вичерпними, допускається їх перетин, їх відношення до свого змісту досить проблематичне;

- позиція вчителя не авторитарна, вона відкрита спростуванню (тобто готовності визнати помилку);

- передбачається, що учні стають вдумливими, рефлексивними, все більш розсудливими;

- фокус освітнього процесу спрямований не на поглинання інформації, а на осягнення внутрішніх відносин досліджуваних предметів [7, с. 98].

Автор вважає, що 3 самого початку зрозуміло, що рефлексивна парадигма розглядає освіту як дослідження, в той час як стандартна парадигма має інше бачення. Звідси і розбіжності про умови протікання навчання і 3 приводу переслідуваних цілей. Існує різниця між тим, що зроблено і тим, як зроблено. Наприклад, в стандартній парадигмі вчителі опитують учнів; в рефлексивній парадигмі вчителі та учні задаються 
питаннями. В стандартній парадигмі учні вважаються мислячими в тому випадку, якщо вони вивчили те, чому їх навчають; в рефлексивній парадигмі учні вважаються мислячими, коли вони приймають участь у співтоваристві дослідників.

На нашу думку, саме впровадження рефлексивної парадигми в практику роботи сучасної української школи створить необхідні умови для розв'язання освітніх задач, які полягають у необхідності активізаціі пізнавальної діяльності учня, перетворення його із об'єкта у суб'єкт учіння.

Характеризуючи рефлексивну парадигму, М. Ліпман використовує ключові поняття, які не є точними, на його думку, чітко окресленими; навпаки, вони швидше дифузні та контекстуальні. Це: дослідження, співтовариство, раціональність, справедливість, творчість, автономія. Кожне 3 цих понять несе в собі дещо більше, ніж просто дух традиційної філософії. Автор підкреслює, що такого роду поняття, які з'єднують принципи, наслідки, які витікають 3 них - тільки абстрактна, теоретична сторона критичного підходу. «Якщо нам не вдасться з'єднати все це 3 практикою - способами, якими рефлексивна освіта може фізично працювати в класі, - ми скотимося до культивування хибного розуміння, яке властиве відстороненим від теорії людям і повністю поглинутих практикою», - підкреслює М. Ліпман [7, с. 99].

Виходячи 3 переконань Д. Дьюї про те, що освіта зазнавала невдачі через суттєву помилку, яка полягала у тому, що вона намагалась примусити учнів вивчати висновки, а не досліджувати проблеми, залучаючи їх в цю діяльність, М.Ліпман теж розглядає освітній процес у класі як наукове дослідження, а шкільний клас як дослідницьке співтовариство, яке «мислилося філософом як основа суспільства, в якому відбувається становлення громадян демократичного суспільства» [1, с. 282]. «Запропонований Д. Дьюї шлях... полягає у тому, що в якості зразка освітній процес в класі повинен орієнтуватися на процес наукового дослідження», - пише М. Ліпман. У такому класі як співтоваристві учні слухають один одного 3 повагою, висловлюють ідеї з урахуванням ідей інших, закликають наводити докази у випадку сумнівних думок, допомагають один одному робити висновки зі сказаного. [7, с. 100].

Для того, щоб у класі відбувалося мислення, програма, за якою він працює, не повинна бути чіткою i жорстко структурованою, оскільки останнє паралізує думку. Програма повинна акцентувати аспекти предмету, не вирішені і проблематичні, з метою привернення до них уваги учнів, стимулювання їх до створення співтовариства дослідників, розвивати чутливість до проблемного, розсудливість, формувати відношення i створювати умови для формулювання суджень і характеристик. Судження $є$ вирішеннями чи визначеннями того, що спочатку було не вирішеним, не визначеним, так чи інше проблемним. «Ми можемо сказати, - пише М. Ліпман, - що дослідження і судження в цілому співвідносяться одне 3 одним як процес і продукт, однак, цим зв'язок не вичерпується; деякі дослідження не виливаються в судження, а деякі судження не є продуктом 
дослідження. Проте, результати дослідження, як правило, резюмуються і виражаються в оціночному характері процесу дослідження : оцінювання породжує оцінки, опис створює зображення, аналітична робота дає аналіз» [7, с. 102].

Звертання до словників дозволяє дізнатися, пише М. Ліпман, що судження $\epsilon$ «формуванням думок, оцінок або висновків». Отже, воно містить такі речі, як вирішення проблем, вироблення рішень, опанування нових понять, але, разом 3 тим, є ширшим та загальнішим. Судження є результатом критичного мислення. За М. Ліпманом судження можуть бути оціночними, прескриптивними, приписовими, дескриптивними, описовими [8, с. 34].

Науковець поділяє думку Е. Херста з приводу того, що «наукове знання виступає моделлю раціональності» i повинне «підтверджуватися очевидністю чи підгрунтям». Тому учнів слід орієнтувати саме на таке розуміння знання, на те, що ніяке судження не можна виносити без адекватних і відповідних критеріїв [7, с. 103].

Шляхом укріплення об'єктивності суджень є критерії. До них М. Ліпман відносить : стандарти, закони, правила, канони, інструкції, приписи, вимоги, умови, обмежання, конвенціі, принципи, припущення, визначення, ідеали, цілі, завдання, методи, процедури та ін. Критерії належать до найважливіших інструментів раціональної діяльності, $є$ суттєвим моментом навчання критичного мислення, підкреслює дослідник $[8$, c. 40].

У критичному мисленні задіюється велика кількість пізнавальних навичок, об'єднаних у групи, наприклад, навичок формування умовиводів, концептів, дослідження і перекладу. Усі їх слід враховувати у розвитку критичного мислення. Нехтування бодай однією 3 них призведе до руйнування процесу в цілому [8].

Рефлексивну модель освіти часто відрізняють від стандартної, виходячи із спрямованості першої, перш за все, на автономію того, хто вчиться. На жаль, пише М. Ліпман, автономія часто асоціюється з чимось на кшталт «вульгарного індивідуалізму». Насправді, рефлексивна модель повністю соціальна і комунальна, іiі метою є артикуляція відмінностей, які породжують в співтоваристві групові уособлення, розробка аргументів в підтримку конкуруючих тверджень і досягнень в процесі ретельного обговорення розуміння загальної картини, яка дозволяє зробити об'єктивне судження. «Рефлексивна модель освіти навчає учнів мисленню вищого порядку, якому властиві понятійне багатство, послідовне, організоване, орієнтоване на пояснення мислення»", - підкреслює автор [7, с. 105]. Інструментом стимуляції його в навчальному класі $є$ філософствування або роблення філософіi [to do philosophy]. Воно перетворює клас у «співтовариство дослідників». М. Ліпман вважає, що введення методології співтовариства дослідників у будь-яку дисципліну може стати засобом стимуляції обговорення і рефлексії про ії предмет. Прийоми критичного мислення створюють рамки, які дозволяють залучати в дискусію 
предметний зміст даної дисципліни [7, с. 106].

Мислення вищого порядку не зводиться тільки до критичного, швидше воно є сплавом критичного і творчого мислення. Таке мислення $є$ продуктивним і гнучким.

М. Ліпман підкреслює, що майстерне мислення включає ще і третій компонент - комплексне мислення як мислення, яке усвідомлює як власні передбачення, так і причини і докази на користь того чи іншого висновку [7, с. 109].

Науковець вважає, що сьогодні школа вимагає змін, вся ії діяльність потребує перегляду. «Рефлексія відносно практики - це основа для створення більш досконалої практики, а остання, в свою чергу буде стимулювати подальшу рефлексію i послідуючу корекцію практики» $[7$, с. 111]. Школа, побудована на таких засадах, буде готувати розсудливих громадян, в яких відчуває потребу здорова демократія.

Рефлексивна модель освіти М. Ліпмана сьогодні $є$ підгрунтям організації навчання учнів у деяких країнах світу, зокрема у Фінляндії про успіхи якої ми говорили вище [див. с. 1].

Значну роль у досягненнях фінської системи освіти відіграла психолого-педагогічна наука. Фінська педагогіка як в теорії, так і на практиці, покликана забезпечити політичну ідею рівності. У психологопедагогічних теоріях 70-х років, відзначає В. Загвоздкін, спостерігається рішуча відмова від уваги до вроджених здібностей і перехід до вивчення таких, які впливають на процес навчання... У відповідності до цього навчання потрібно диференціювати так, що різний час, який потрібний різним учням для засвоєння матерілу, повинен стати визнаною складовою частиною системи [4].

У якості дидактичної моделі, яка забезпечує цей процес, була вибрана концепщія американського педагога Б. Блума (B. Bloom) «mastery learning», згідно якої центральним елементом навчального процесу $\epsilon$ ретельне формулювання (визначення) навчальних цілей і наступна деталізація їх по окремих кроках, де для кожного знову точно формулюється навчальна мета. Досягнення цих цілей повинно бути своєчасно відслідковане. Суттєву роль тут відіграє принцип подолання труднощів, згідно якого важливе завдання навчального процесу полягає у своєчасному визначенні труднощів, з якими зустрічається учень і допомозі йому у подоланні їх. Важлива також і система оцінки навчальних досягнень : оцінки, які дозволяють порівнювати одного учня 3 іншим, були усунуті. Зусилля направляються на сприймання учнем своїх навчальних досягнень прогресу в навчанні, який повинен посилити довіру учня до себе, своїх здібностей і підвищити позитивне відношення до процесу навчання. Уже на ранніх етапах практикується самооцінка [15].

Останніми роками, вважає В. Загвоздкін, намітився перехід від концепції Б. Блума в основі якої лежали моделі навчання біохевіористського толку, до конструктивістських моделей навчання, в основі яких ідеї Ж. Піаже. У них підкреслюється власна активність учнів у навчанні. 
За основним положенням конструктивізму, знання не надається учням, а створюється ними. Це відображає думку швейцарського психолога Ж. Піаже про те, що дитина завдяки взаємодії з оточуючим світом створює для себе правила, згідно з якими і здійснюється подальша взаємодія. Дитина сама впорядковує цю взаємодію. Вчитель повинен виступати посередником між знанням та учнем, тобто повинен направляти учня. Задача вчителя підтримувати учня у його починаннях [4].

Світ майбутнього потребує таких навичок у людей, як творче i критичне мислення, здатність учитися. «Фінляндія зі свою системою PBL (phenomenon-based teaching and learning - англ. «феномено-орієнтоване навчання та викладання», або простіше «викладання і вивчення явищ») уже сьогодні вчить людей майбутнього, зносячи стіни у школах і прибираючи звичні «предмети» із розкладу уроків», - вважає М. Писаревський [10].

Автор констатує, що у вільній атмосфері проходять навчання групи чи класи, зібрані з дітей різного віку. При цьому на «уроках» не викладають окремі предмети - математику, фізику чи географію, а вивчають «феномени», «явища», розглядають якісь практичні приклади з реального життя. Таким чином у Фінляндії зламані бар'єри не тільки між приміщеннями, але і між класами та предметами, тож, цілком очікувано, що не так давно у Фінляндії був анонсований перехід на «багатодисциплінарне навчання».

У шкільному розкладі таким «урокам із життя» (вивченню феноменів) надається особливий час - ім відводиться досить тривалий період у навчальному році. Метод, який має міжнародну назву PBL (phenomenonbased teaching and learning - англ. «феномено-орієнтовне навчання та викладання», або простіше: «викладання і вивчення явищ»), багато в чому став результатом еволюції методів науково-практичних інтенсивів i методики навчання Task Based Learning and Teaching («навчання i викладання, орієнтоване на вирішення конкретного завдання»). А вони, в свою чергу, у багатьох освітніх закладах прийшли на зміну найбільш звичної системи РPP (Presentation - Practice - Production), коли спочатку іде «начитка» лекцій, потім учні роблять вправи, а далі переходять до використання вивченного на більш практичних прикладах.

Учні в школах без стін і шкільних предметів самі вирішують (або приймають активну участь у рішенні), який «феномен» вони будуть розглядати на наступній сесії, знаходять тему, до якої в них більш усього лежить душа. Різні методи та стратегії стимулювання учнів ставити запитання є важливим засобом розвитку в них навичок аналізу, синтезу, інтерпретації інформації. Здавалося б, такий загальний підхід до вивчення світу повинен знизити рівень знань учнів з окремих дисциплін, зауважує М. Писаревський. Однак, як пояснюють прихильники методу PBL, усі процеси, усі події і дії в реальному житті не поділяються на науки та дисципліни - будь-яка життєва ситуація комплексна і задіює декілька наук відразу. Розум людини теж простіше сприймає інформацію і знаходить вихід із проблем, підходячи до питання комплексно. «У школярів 
розвивається критичне мислення» [10], у якому задіюються різні пізнавальні навички, формується системне мислення, а на підгрунті певних правил, законів як критеріїв (інструментів раціональної діяльності) формулюються судження, які містять свідчення про опанування нових понять, вирішення проблем, наявність висновків, формується позитивне емоційне ставлення до пізнання.

Важливо, що діти, які увійшли в життя з таким багажем знань і вмінь, зможуть вижити в «епоху постправди». Термін «постправда» (post truth) був визнаний найпопулярнішим словом 2016 р. в англійській мові. Цей феномен використовують як інноваційну, соціальну i політичну технологію, коли основою дискурсу стає не факт, а емоційна складова. Саме система PBL не притупляє емоції учнів, які залишаються живими людьми в комфортному середовищі, допомагає заглянути за сенс сказаних слів, побачити факти, а за ними - і явища. «Докопатися і усвідомити саму суть явищ - в цьому мета нової системи освіти», - підкреслює М. Писаревський [10].

Зазначимо, що в 20-х роках XX століття в українській школі теж була спроба відмовитись від класно-урочної системи навчання. Поширювалася комплексна система навчання (від лат. complecus - зв'язок, сполучення), яка передбачала відбір змісту освіти та його відповідну інтеграцію навколо тем, що дозволяло ознайомлювати учнів 3 природою, суспільством, працею людей. Однак, таке навчання, побудоване на основі широкої міжпредметної інтеграції, виявилося непродуктивним, бо не забезпечувало формування в учнів систематичних і грунтовних знань і вмінь [12, С. 11-12; 260].

Викладене дозволяє констатувати, що ідеї німецького філософа I. Канта про роль рефлексії у пізнанні актуальні сьогодні. Про це свідчить звертання американського дослідника М. Ліпмана до ідей I. Канта про рефлексію як спосіб утворення нових понять і суджень і розробка ним рефлексивної моделі практики освіти. Побудова процесу навчання у фінській школі має, на нашу думку, ознаки рефлексивної парадигми критичної практики освіти, а саме :

- навчання - це результат участі у керованому учителем співтоваристві дослідників;

- інтегративність навчання як підхід, що допускає перетин навчальних дисциплін;

- вивчення не окремих предметів, а феноменів, явищ, у виборі яких беруть участь учні;

- відсутність чітких жорстко структурованих програм - колегія кожної школи сама розробляє програму і навчальні плани;

- клас - це співтовариство дослідників;

- у класі-співтоваристві є філософствування або «роблення філософіï», що стимулює обговорення і рефлексію;

- фокус освітнього процесу спрямований не на поглинання інформації, а на усвідомлення внутрішньої суті явищ, феноменів; 
- позиція вчителя не авторитарна, його авторитет - у високому професіоналізмі;

- у процесі навчання звичайна практика перетворюється у критичну, що сприяє формуванню в учнів мислення, якому властиві критичність і творчість.

Побудована на положеннях філософії І. Канта, рефлексивна модель практики освіти М. Ліпмана утверджує ідею про те, що для «одержання більш розумних людей з учнями, які пропускаються через школу, слід поводитися розумно. Регулюючими ідеями цієї моделі $є$ розумність, креативність і демократія.

Епоха глобальних соціально-економічних змін чітко означила потребу у вихованні людей, яким властиве мислення, що є сплавом критичного і творчого. Таке мислення є підгрунтям для успішної життєдіяльності в інформаційному суспільстві XXI століття.

Сучасна Фінляндія, запозичивши позитивний досвід організації освітянських систем в інших країнах світу, зокрема, США, Швеції, Німеччини та ін, відмовившись від концепції Б. Блума і перейшовши до моделей навчання, в основі яких ідеї Ж. Піаже про максимальну активність учня у процесі навчання, пішла своїм шляхом і створила систему освіти, яка цікавить усіх, хто займається навчанням і вихованням підростаючого покоління у світі.

Досвід освітян Фінляндії може бути використаний при розбудові «нової школи» в Україні, зокрема, при вирішенні завдань виховання в учнів критичного мислення та впровадженні інтегрованого навчання у старшій школі.

\section{ЛІТЕРАТУРА}

1. Адаменко Н. «Спільнота дослідників» М. Ліпмана : філософські запитування, обговорення, аргументації та контраргументації вустами дітей. Філософія освіти: наук. часопис. 2011. № 1-2. С. 275-287.

2. Гринюк С. П. Сумлінна праця: як фіни побудували успішну систему освіти // Вісник післядипломної освіти. 2011. Вип. 5. С. 57-64.

3. Жадяєв Д. В. О понятии рефлексии у И. Канта URL : http:/ / www.info-library.com.ua/books-text-11951.html

4. Загвоздкин В. Секрет финского успеха. Народное образование. 2006. № 14. С. 57-66.

5. Кант И. Критика чистого разума. Москва : Эксмо. 2006. 736 с.

6. Кузьмин А. А. Типология транцендентальной рефлексии в философии И. Канта.

7. Липман М. Рефлексивная модель практики образования. Перевод выполнен А. В. Колотвиным по The reflective model of educational practice. Lipman M. Thinking in Education. Cambridge. 1991. P.7-25. URL : http://window.edu.ru/resource/200/42200/files/pril1_1.pdf

8. Ліпман М. Критичне мислення : чим воно може бути? Постметодика. 2005. № 2 (60). С. 33-41. 
9. Ожегов С. И. Словарь русского языка : 7000 словю. Москва : Русс. яз., 1989. $924 \mathrm{c}$.

10. Писаревский М. Образование в Финляндии: школы без стен, учеба без оценок URL: https://innovationhouse.org.ua/ru/statti/obrazovanye-vfynlyandyy-shkoly-bez-sten-ucheba-bez-otsenok/.

11. Родюк Н. Ю, Лазаренко Н. І., Доті Чед. Інноваційні процеси в розвитку вищої освіти Фінляндії. Молодий вчений. 2018. N 5.2 (57. 2). С. 38-41.

12. Савченко О. Я. Дидактика початкової школи : підручник для студентів педагогічних факультетів. Київ : Генеза. 1999. 368 с.

13. Словарь иностранных слов. Москва : Русс. яз. 1988. 608 с.

14. Философский энциклопедический словарь. Москва : Иностр. л-ра, 2003. $576 \mathrm{c}$.

15. Krathwohl D. R. Bloom. Taxonomy of educational objectives.

\section{REFERENCES}

1. Adamenko, N. (2011). «Spilnota doslidnykiv» M. Lipmana : filosofski zapytuvannia, obhovorennia, arhumentatsii ta kontrarhumentatsii vustamy ditei [M. Lipman's «Community of Researchers»: Philosophical Questions. Discussions, Arguments and Counter-Arguments through Children's Mouths]. Filosofiia osvity : nauk. chasopys. № 1-2. S. 275-287.

2. Hryniuk, S. P. (2011). Sumlinna pratsia: yak finy pobuduvaly uspishnu systemu osvity [Hard work: how the Finns built a successful education system] // Visnyk pisliadyplomnoi osvity. Vyp. 5. S. 57-64.

3. Zhadiaiev, D. V. O poniatyy refleksyy u Y. Kanta [On the concept of reflection in I. Kant] URL: http://www.info-library.com.ua/books-text11951.html.

4. Zahvozdkyn, V. (2006). Sekret fynskoho uspekha [The secret of Finnish success]. Narodnoe obrazovanye. № 14. S. 57-66.

5. Kant, Y. Krytyka chystoho razuma. [Criticism of Pure Reason] Moskva : Эksmo. 2006. $736 \mathrm{~s}$.

6. Kuzmyn, A. A. Typolohyia trantsendentalnoi refleksyy $\mathrm{v}$ fylosofyy Y. Kanta [Typology of transcendental reflection in the philosophy of I. Kant].

7. Lypman, M. Refleksyvnaia model praktyky obrazovanyia. [Reflexive model of educational practice] URL : http://window.edu.ru/resource/200/42200/files/pril1_1.pdf

8. Lipman, M. Krytychne myslennia: chym vono mozhe buty? [Critical thinking: what can it be??]. Postmetodyka. 2005. № 2 (60). C. 33-41.

9. Ozhegov, S. I. Slovar` russkogo yazy`ka : 7000 slov. Moskva : Russ. yaz., 1989. $924 \mathrm{~s}$.

10. Pisarevskij, M. Obrazovanie v Finlyandii: shkoly` bez sten, ucheba bez oczenok [Education in Finland: schools without walls, studies without grades] URL: https://innovationhouse.org.ua/ru/statti/obrazovanye-v-fynlyandyyshkoly-bez-sten-ucheba-bez-otsenok/.

11. Rodiuk, N. Iu, Lazarenko,N. I., (2018). Doti Ched. Innovatsiini protsesy v rozvytku vyshchoi osvity Finliandii [Innovative processes in the development 
of higher education in Finland]. Molodyi vchenyi. N 5.2 (57. 2). S. 38-41.

12. Savchenko, O. Ya. (1999). Dydaktyka pochatkovoi shkoly: pidruchnyk dlia studentiv pedahohichnykh fakultetiv. Kyiv : Heneza. $368 \mathrm{~s}$

13. Slovar` inostranny`kh slov. (1988). [Dictionary of foreign words]. Moskva : Russ. yaz. 608 s.

14. Filosofskij e`ncziklopedicheskij slovar`. (2003). [Philosophical Encyclopedic Dictionary] Moskva: Inostr. 1-ra, 576 s.

15. Krathwohl, D. R., Bloom. Taxonomy of educational objectives.

Рецензент: д. пед. н., проф. Дороніна Т.О.

leftmail133@gmail.com 